\title{
Economic Crises and the Welfare State in Korea: Reforms and Future Challenges*
}

\author{
Huck-ju Kwon, ${ }^{* *}$ Grami Dong,*** and Hyun-gyung Moon*****
}

\begin{abstract}
East Asian countries have been hit yet again by economic crisis, this time of a global nature, after having endured the Asian economic crisis of 199798. Social protection for the weak in society during the crisis poses a great policy challenge. This paper examines Korea's social policy responses to these economic crises in the context of the evolution of the welfare state. Faced with the economic crisis of 1997-98, the welfare state was extended and strengthened in terms of coverage and benefits in order to facilitate labor market reform. In the current global economic crisis, social policies such as public assistance and unemployment benefits, together with extra job-retaining measures that the government put into place, have enabled Korea to respond much more effectively to social risks arising from the crisis than it did during the earlier Asian crisis. However, it is imperative for Korea to further strengthen the welfare state, particularly in the areas of social services for children and the elderly, in order to maintain its economic potential in the face of dramatic demographic transitions and changes in family structure that are likely to occur in the future.
\end{abstract}

Keywords: economic crises, social protection, developmental welfare state, demographic transitions, social services

* Earlier versions of this paper were presented at the Social Protection in Asia: Annual Conference and Research Workshop, in Hanoi, Vietnam, June 1-5, 2009, and at the Public Administration and Governance in a Time of Global Economic Turbulence conference, organized by the Korea Institute of Public Administration (KIPA), in Seoul, Korea, October 9, 2009. Thanks are due to Ashwani Saith, Naila Kabeer, and Stephen Wilks for their comments. State any caveats explicitly.

** Huck-ju Kwon is Associate Professor and the Deputy Director of BK(Brain Korea)21 in the Graduate School of Public Administration, Seoul National University. He is interested in policy process, international development, global governance, and social policies in East Asia. E-mail: hkwon4@snu.ac.kr.

*** Grami Dong is a graduate student in the Graduate School of Public Administration, Seoul National University. Her interests include public accountability, poverty reduction, and international development. E-mail: grami@snu.ac.kr.

**** Hyun-gyung Moon is a graduate student in the Graduate School of Public Administration, Seoul National University. His interests include comparative social policies, historical institutionalism, and European governance.E-mail: goldmedal6@snu.ac.kr.

Manuscript received February 13, 2010; out for review March 8, 2010; review completed April 5, 2010; accepted April 13, 2010.

The Korean Journal of Policy Studies, Vol. 25, No. 1, 175-192 (2010)

(C) 2010 by the GSPA, Seoul National University 


\section{INTRODUCTION}

East Asian countries have been hit yet again by economic crisis, this time of a global nature, after having endured the Asian economic crisis of 1997-98. The current crisis has turned out to be less serious so far than had been feared, because most governments in the industrialized countries responded swiftly, in a concerted effort to avoid a deep recession. This is an important difference from the last great depression in the 1930s, when the governments of the major economies in the world responded inadequately and did not work together to overcome their economic difficulties.

From an East Asian perspective, the current global economic crisis is different from the crisis of 1997-98. Most importantly, it did not originate in East Asia. The epicenter of the crisis was at the heart of global capitalism: Wall Street financial institutions. Since the crisis did not directly hit East Asian countries-for example, China, Japan, and Korea ${ }^{1}$-it did not immediately bring about social crisis as the previous Asian economic crisis did ten years ago. For example, the unemployment rate in Korea in recent months has remained just above 3 percent. China's savings rate is still around 50 percent of GDP, mostly accounted for by government reserves and individual citizens' savings accounts (He and Cao 2007).

Nevertheless, the economic crisis has affected many East Asian economies and has called into question the viability of the export-oriented strategy that had been successful for many years. The economic crisis also raised the question whether existing welfare systems can cope with the social contingencies that arise in a period of economic downturn. This paper applies this question to the case of Korea and explores new policy directions that can cope with social risks arising in the future.

At the end of 1997, when the Korean economy was on the brink of collapse, the Korean government quickly responded with a wide range of reforms, including labormarket reform. There was a social consensus that the existing social policy programs should be strengthened and new programs be introduced in order to avoid further social crisis. After ten years, the welfare state ${ }^{2}$ in Korea has evolved into a fairly comprehensive system. With such evolution and growth, can the existing welfare state in Korea cope with new social risks arising from the global economic crisis and from long-term social change?

In order to answer these questions, this paper will first briefly review the structural

1. Korea refers to the Republic of Korea throughout this paper.

2. The term "welfare state" in this paper refers to a set of public policies and institutions that aim to protect citizens against poverty and social contingencies. This does not necessarily mean that the level of social protection is adequate or that welfare programs are comprehensive. 
basis that has shaped the economic and social dynamics of the welfare state in Korea since the 1960s, arguing that the welfare state only protected narrow groups of people, focused on promoting industrialization, and was established on the basis of high social mobility and relative equality. Second, it will trace the path of welfare reform after the economic crisis of the late 1990s and examine whether the emerging welfare state was better prepared to take on social risks in the context of the global economic recession. Last, it will examine the policy responses of the Korean government and identify a future policy direction in order to maintain the economic potential of the country and to provide adequate social protection to its citizens.

\section{THE WELFARE STATE AND THE SOCIAL STRUCTURE IN KOREA: A HISTORICAL PERSPECTIVE}

The literature on social policy in East Asia-including Korea-maintains that social policies have been used as an effective tool for economic development (Goodman and White 1998; Holliday 2000). The people initially protected by social policy programs were civil servants and workers employed in strategic industries so that they could be mobilized for economic development (Yi 2007). For instance, Industrial Accident Insurance was introduced in 1961 as the first social welfare program, implemented from 1963 along with a pilot program for health insurance effected by the military government that took power after a coup d'etat in 1961. It was considered necessary as Korea embarked on an ambitious economic development plan. At the beginning, Industrial Accident Insurance covered people in workplaces of 500 employees or more. In 1962, the government made the existing civil service pension program more generous, to mobilize the bureaucracy for economic development.

These characteristics of a so-called developmental welfare state were further reinforced throughout the 1970s and 1980s, during which the Korean economy recorded an impressive growth. In 1973, the National Pension Program was first considered as an effective measure for increasing domestic savings: capital could be used for industrialization. It was, however, postponed due to the sudden oil price rise and subsequent inflation. The National Pension Program was eventually implemented in 1988 with people working in large firms. National Health Insurance, which was introduced in 1977 for workers in enterprises with more than 500 workers, was introduced under the same policy orientation. Meanwhile, the income support program for the poor was based on a very restrictive means test and provided minimum benefits. Also, there was no income support for the unemployed during the period of rapid economic growth until its introduction in 1995. 
Because of these characteristics, social policies tended to have little impact on poverty reduction and income inequality (Kwon 2001). Given that economic growth does not necessarily lead to poverty reduction, and that the focus of social policy in Korea would not have reduced the widespread poverty, one may expect that income distribution and the level of poverty in Korea would have not been improved by economic development. The historical experience, however, shows the contrary, and it is necessary to review briefly the social structure of Korean society in order to understand this.

The important key to understanding such social outcomes is the social and economic structure established before economic development took off in Korea. Two main structural factors related to poverty reduction are the high degree of social mobility, which was enhanced by Korea's land reform and an explosive increase in mass education (World Bank 2006), and the role of the state (Wade 1990). The importance of land reform, which occurred in three waves from 1946 to 1955, is not so much its impact on the development of the agricultural sector as the structural changes it effected in state-society relations. Land reform created small, independent farmers who had been tenants of Korean and Japanese landlords under Japanese rule (1910-1945). Its immediate effects were reduction in inequalities in landownership, but enabled farmers to send their children to school with the increased surplus in production. With a massive increase in education, the Korean government was able to push industrialization successfully beginning in the 1960s.

It is also important to know that the government mobilized and coordinated public institutions to perform multiple-and sometimes contradictory-functions of social protection and poverty reduction in the absence of explicit social policies regarding these goals (Kwon and Yi 2009). For example, agricultural cooperatives play the role of banks for farmers, eliminating usurious loans in rural areas in the 1960s ; public health centers performed preventative outreach using community-based activities ; and vocational training programs helped give young people the necessary skills to participate in the labor market (Yi 2007). In short, public institutions were mobilized by the state to carry out de facto social policy. In addition, income distribution was maintained during the period of rapid economic growth. This helped close the gap between low and high incomes. Table 1 shows the trend of income inequality in Korea from the 1960 s to the 1990 s. 
Table 1. Income Inequality in Korea

\begin{tabular}{llllllll}
\hline & 1965 & 1970 & 1976 & 1982 & 1988 & 1990 & 1993 \\
\hline Gini index & 0.344 & 0.332 & 0.391 & 0.357 & 0.337 & 0.323 & 0.310 \\
Decile ratio & 0.463 & 0.472 & 0.372 & 0.437 & 0.466 & 0.507 & 0.520 \\
\hline
\end{tabular}

The Gini index represents the measure of inequality of income distribution. A lower Gini figure means more equal income distribution.

The Decile ratio represents the ratio of the income of the poorest 40 percent to that of the richest 20 percent. Source: National Statistical Office (http://kostat.go.kr)

\section{WELFARE REFORM AFTER THE ASIAN ECONOMIC CRISIS OF 1997-98}

The explicit social policies that have been introduced since the 1960s were geared for economic development and covered only a narrow section of the population. This preoccupation with economic development led to the welfare state being predominantly composed of social insurance programs, under which people were required to pay contributions prior to entitlement to social benefits. As a result, only selected groups of people, particularly those with formal employment, had access to social protection, while vulnerable sections of the population were left outside the system. To avoid a demand for universal entitlement, the state did not provide funding for the welfare programs, but enforced the rules, formal and informal, that regulated the payment of contributions for social benefits by companies and their employees. The social insurance programs were operated by quasi-governmental agencies, working at arm's length from the government and not strictly speaking part of it (Kwon, 1999).

In the 1990s, the social conditions that had maintained the developmental welfare state began to disappear. As trade unions became able to mobilize workers to protect

their interests, Korea was faced with higher costs and lower productivity increases. It was true that the Korean government, prior to the Asian economic crisis of 1997-98, attempted to carry out economic reform aimed at a high-technology and productivitybased economy to avoid an economic deadlock. However, political parties, trade unions, and civil society groups strongly opposed this effort because they feared that economic reform would lead to social disaster given the inadequacy of social protection.

The inability of the Korean government to carry out the reform undermined its credibility among international financial investors, and the economic crisis that had started in Thailand hit Korea in 1997. The Asian economic crisis forced Korean society to accept economic reform, and at the same time produced a surprise victory for the center-left opposition in the presidential election at the end of 1997. The new Korean 
government established a tripartite committee, the Labor-Employers-Government Committee, which was able to produce a broad-based social consensus for economic reform while strengthening the welfare state (Kwon, 2005).

As already mentioned, considerable downsides had been identified in the developmental welfare state in Korea before the Asian economic crisis. There were social pressure groups, some forming strong advocacy coalitions for a more inclusive social policy that strengthened social protection for the poor and vulnerable. Nevertheless, these efforts did not prevail before the crisis of 1997-98. During that crisis, it became clear that the developmental welfare state could not cope with social challenges in an economic downturn. In particular, the developmental welfare state was not able to tackle high unemployment since it was based on the assumption of full employment (see table 2).

Table 2. Unemployment Rates in East Asia

\begin{tabular}{lccccccccc}
\hline & 1996 & 1997 & 1998 & 1999 & 2000 & 2001 & 2002 & 2003 & 2004 \\
\hline Hong Kong & 2.8 & 2.2 & 4.7 & 6.2 & 4.9 & 5.1 & 7.3 & 7.9 & 6.8 \\
Korea & 2.0 & 2.6 & 7.0 & 6.3 & 4.1 & 3.8 & 3.1 & 3.4 & 3.5 \\
M alaysia & 2.6 & 2.4 & 3.2 & 3.4 & 3.1 & 3.6 & 3.4 & 3.6 & 3.5 \\
Singapore & 3.0 & 2.4 & 2.5 & 3.6 & 3.5 & 2.8 & 4.3 & 4.7 & 4.0 \\
Thailand & 1.1 & 0.9 & 3.4 & 3.0 & 2.4 & 2.6 & 1.8 & 2.2 & 2.1 \\
Taiwan & 2.6 & 2.7 & 2.7 & 2.9 & 3.0 & 4.6 & 5.2 & 5.0 & 4.4 \\
\hline
\end{tabular}

Sources: Asian Development Bank, Asian Development Outlook (http://ww w .adb.org/Documents/Books/AD0)

Faced with a severe economic crisis, the Korean government quickly implemented social policy reforms that would enhance social protection for the vulnerable. This swift response was also related to economic restructuring. Before the economic crisis, it was well observed by the government that productivity and international competitiveness had deteriorated during the 1990s due to rising costs, including wage increases and competition from other East Asian countries such as China and Thailand (Park 2001). Wages increased more than labor productivity in this period. Structural reform to overcome the crisis would inevitably create a large number of the unemployed, but social policy remained too weak to deal with this-although the main social policy programs, which had started with workers, were expanded beyond large-scale workplaces, public assistance for the poor remained limited with a tight means test.

Civil society organizations played an important role in the expansion of social policy coverage, advocating for wider social protection and the Minimum Living Standard Guarantee. The Employment Insurance Program, which consisted of unemployment benefits and training schemes, was extended and strengthened in terms of coverage 
and benefits. A new social-assistance program was also introduced to replace the old one. The advocacy coalitions of civil society organizations pursued the integration of the fragmented National Health Insurance, which resulted in a new National Health Insurance Corporation, a single national agency for health insurance administration and finance. Through this process, the notion of social rights was added to economic development as an important rationale for the welfare state.

Despite all these changes, the welfare state in Korea maintains the features of a development welfare state in two ways: First, the welfare reform was carried out to meet the policy demand of labor market reform. Second, human capital investment such as training and capacity building remained its most important rationale, in particular with respect to the Minimum Living Standard Guarantee and Employment Insurance Program. To capture such continuity and change, in short, it can be said that Korea's developmental welfare state has moved toward becoming an inclusive developmental welfare state (Kwon 2005). ${ }^{3}$

The emerging structure of the welfare state after the reform comprises five social insurance programs (Industrial Accident Insurance, National Health Insurance, National Pension Program, Employment Insurance Program, and Long-Term Care Insurance), one social assistance program (the Minimum Living Standard Guarantee), and three public pension programs for special categories of people such as civil servants, private school teachers, and military personnel.

Industrial Accident Insurance introduced in 1961, covered people in workplaces of 500 employees or more. Since then, the number of workplaces covered by this program has increased, and at present workplaces with more than one regular employee must join in the program, and 44 percent of employed people were covered in 2005.

National Health Insurance, the second major aspect of Korea's welfare state, which became compulsory in 1977, initially protected workers in large-scale industrial enterprises, public sector workers, and private school teachers. By 1987, most employees in the industrial sector had access to health care through National Health Insurance, while the self-employed, farmers, and others without employers did not. In 1988-89, the democratically elected government extended National Health Insurance to the entire population, providing financial subvention for those people outside National Health Insurance. In 2000, the Kim Dae-jung government integrated the fragmented

3. The term "developmental welfare state" refers to a welfare state in which elite policy makers set economic growth as the fundamental goal, pursue a coherent strategy to achieve it, and use social policy as an instrument for attaining that goal. In other words, the developmental welfare state comprises a set of social policies and institutions that are predominantly structured for facilitating economic development. 
structure of the program into a national administrative body.

The third main program, the National Pension Program, was first considered for introduction in the early 1970s, but implementation was postponed due to the 1973 oil crisis. It was eventually reintroduced in 1988. Due to the insurance arrangement, the National Pension Program, like National Health Insurance, began with formal sector employees, and by 1994 it covered 26.7 percent of the working population (Kwon 1999). In 1999, farmers, the self-employed, and those with short-term contracts joined the program. The Employment Insurance Program was implemented in 1995. As its name implies, it comprises not only unemployment benefits but also job security grants and training grants. While unemployment benefits are paid to those who lose their jobs, job security grants subsidize employers who retain their employees instead of laying them off. Training grants are paid to training institutions, private or public, for training unemployed people, while the unemployed are eligible for training allowances during their period of training. During the economic crisis, the percentage of those receiving unemployment benefits went up to 33.1 percent in 1999 from 7.8 percent in 1997 (Employment Insurance Corporation 2001).

A new social insurance program, which has been implemented since 2008, is longterm care insurance. The basic structure of the program is social insurance, which collects contributions from citizens and provides care to people over sixty who require long-term care due to difficulties in active daily living. Elderly people who request long-term care are interviewed by social workers who assess their needs. Once their requests are approved, they can use care services either in their homes or in care institutions. Care providers have contracts with National Health Insurance, and service users are required to make copayments.

Of great importance in terms of poverty reduction in response to the economic crisis of 1997-98 was the Minimum Living Standard Guarantee. This is a social assistance program entirely funded by the government (both central and local), replacing an earlier assistance program that was very limited in terms of its scope and level of benefits. The Minimum Living Standard Guarantee uses a much higher poverty line than the earlier program did. It also provides benefits to the poor if their income below the poverty line regardless of their age and family condition-unlike the earlier program, in which people age 18 to 64 , and those with family members who were supposed to help them, were not eligible for benefits. The Minimum Living Standard Guarantee still requires recipients age 18 to 64 to participate in training, public works projects, or community service. 


\section{GLOBAL ECONOMIC RECESSION AND SOCIAL POLICY RESPONSES}

The global economic downturn triggered by the subprime mortgage crisis in the United States hit Korea in 2008 as other East Asian countries. As shown in the figure 1, Korea's economic output fell sharply in the second half of 2008. The impacts of the global economic downturn came through various channels. The volume of exports was slow down as the Korean export to the U.S. and European markets began to stagnate from 2007. But it was international capital in the Korean finance market that made most frantic activities in the second half of 2008, particularly, short-term money market investment. They tried to withdraw investment from the Korean market as deleveraging was taking place in the US and Europe. Opportunistic speculation in Korean currency also put the Korean economy under further pressure. Volatility in the financial market reminded policy makers and the public at large of the East Asian economic crisis ten years earlier. Still, a full-blown economic crisis never materialized in Korea as feared. A currency swapping deal with the Japanese and U.S. governments eased the pressure on the exchange rate, while the high exchange rate reduced the volume of imports and increased exports, which also turned out to be useful in shaking off fears of a crisis.

Figure 1. GDP Growth Rate in Korea

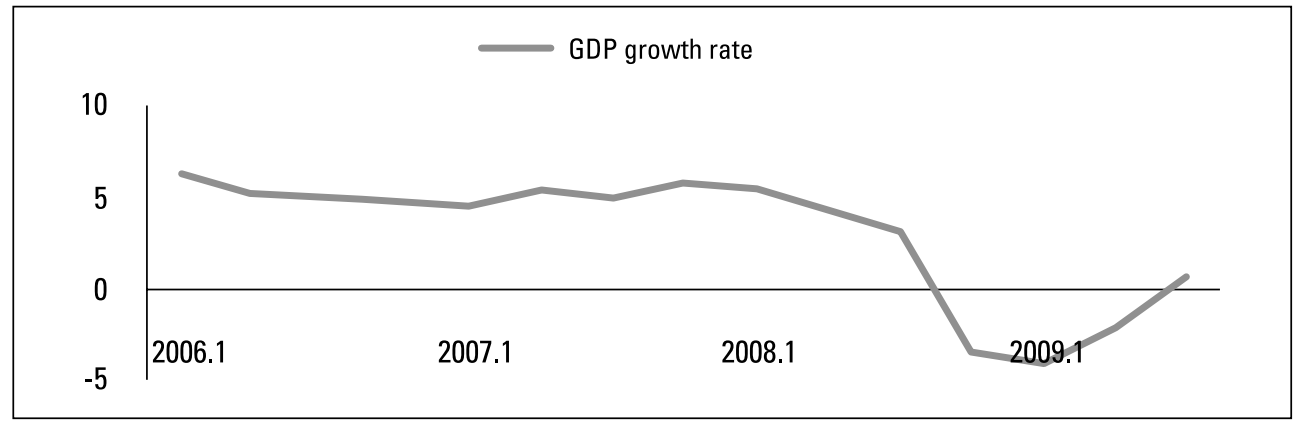

Source: National Statistical Office (http://kostat.go.kr)

Nevertheless, the economic downturn led to an increase in the unemployment rate in 2009, with young people finding it most difficult to find jobs (see table 3). The number of people in the manufacturing, construction, and agricultural sectors decreased, while the number of people in the service sector increased. The Korean government responded to the economic downturn with a special budgetary package in April 2009, an equivalent of 12 percent of the consolidated government budget of the 
previous year, which was an extraordinary size. The package included financial support for small and medium-size firms to create new jobs with regular contracts and to install new equipment, emergency grants to local governments, income support for people with income up to 120 percent of the poverty line, and a public works program designed for young people.

Table 3. Unemployment Trends in Korea

\begin{tabular}{lcccc}
\hline & 2006 & 2007 & 2008 & 2009 \\
\hline Number of unemployed, total & 827,000 & 783,000 & 769,000 & 834,000 \\
Number of unemployed young people & 364,000 & 328,000 & 315,000 & 324,000 \\
Unemployment rate, overall & $3.5 \%$ & $3.2 \%$ & $3.2 \%$ & $3.6 \%$ \\
Unemployment rate among young people & $7.9 \%$ & $7.2 \%$ & $7.2 \%$ & $7.8 \%$ \\
\hline
\end{tabular}

Source: National Statistical Office (http://kostat.go.kr)

The Korean government called the public works program for people just above the poverty line the Huimang (dream) project. It was designed to create about 250,000 public (temporary) jobs, and it would be implemented by the local governments. The jobs ranged from forestry work and local maintenance work to care for the disabled. The average payment is the equivalent of about US\$750 per month.

Figure 2. Employment Rate Trends in Korea (to Previous Quarter)

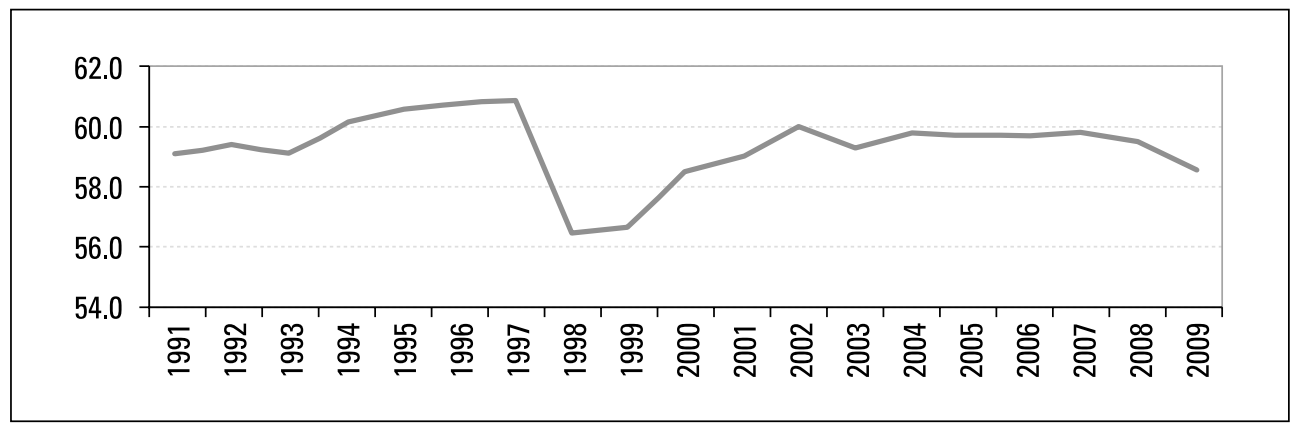

Source: National Statistical Office (http://kostat.go.kr)

Overall, the labor market did not go into deep crisis as in the 1997-98 Asian economic crisis. (Figure 2 clearly shows the magnitude of the difference between the two economic crises.) While the overall impact of the current economic crisis has not been as great in Korea as elsewhere, there is another underlying reason for the difference. Ten years ago, the government was more geared to carrying out reform to make the labor market more flexible, which resulted in a sharp increase in unemployment (see 
table 2). In contrast, responding to the current economic crisis, the government has put effort into retaining existing jobs and creating new jobs in the labor market and temporary jobs through public works.

Another contrast with the earlier crisis is that a range of social policy instruments were already in place to provide social protection, while ten years ago the welfare state was not equipped with adequate instruments to implement policy measures. For instance, in the current economic crisis, the Minimum Living Standard Guarantee and the Employment Insurance Program, which have been in operation for some years, provided an institutional framework for the government policy. Figure 3 shows how the Minimum Living Standard Guarantee responded to the economic recession. There has been a sharp increase in the number of benefit claims since late 2008. During the Asian economic crisis, such social assistance was not available.

Figure 3. M inimum Living Standard Guarantee Claims During the Economic Crisis

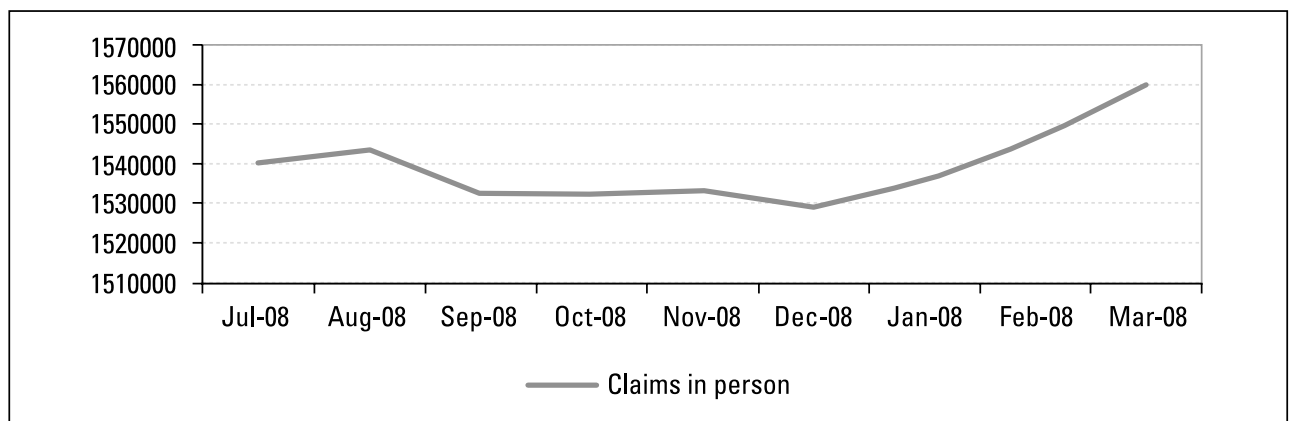

Source: $\operatorname{Im} 2009$.

In relation to social protection for the unemployed, the Employment Insurance Program also responded to the changing situation in the labor market. Table 4 compares the proportion of the unemployed who received unemployment benefits in the two economic crises. At the start of the Asian economic crisis, only 7.8 percent of unemployed people were able to receive unemployment benefits. After extraordinary efforts, the figure crept up to slightly over 30 percent in 1999. In the current wave of rising unemployment, the percentage receiving benefits has been much higher, showing that the existing policy framework worked reasonably well. For instance, at the end of 2009, 40.7 percent of the unemployed received unemployment benefits. Although this does not ensure that the social protection provided was adequate, it can be said that the existing framework of the welfare state responded to the changing economic situation. 
Table 4. Percentage of Unemployed People Receiving Unemployment Benefits in Korea

\begin{tabular}{cccccc}
\hline 1997 & 1998 & 1999 & 2007 & 2008 & 2009 \\
\hline 7.8 & 26.3 & 33.1 & 35.3 & 38.5 & 41.8 \\
\hline
\end{tabular}

Source: Korea Employment Information Service, Employment Issues (http://ww w.keis.or.kr/)

While the Minimum Living Standard Guarantee and Employment Insurance Program were in place for some years before the economic crisis, a few programs were added to the welfare state. The Long-Term Care Insurance program came to effect in 2008, and the Earned Income Tax Credit program, which gives a tax credit to those who are employed but earning just above the poverty line, was implemented in 2008. The Earned Income Tax Credit gives additional cash to those working for low pay, while the Long-Term Care Insurance was designed to create jobs for social workers giving care to the elderly with old- age related disabilities. These programs had been prepared for some years by the government, with the pilot programs undertaken well before the global economic crisis. In other words, they were not introduced in response to the crisis, but they helped to counter the economic downturn.

Figure 4. Government Spending on Social Protection in Korea

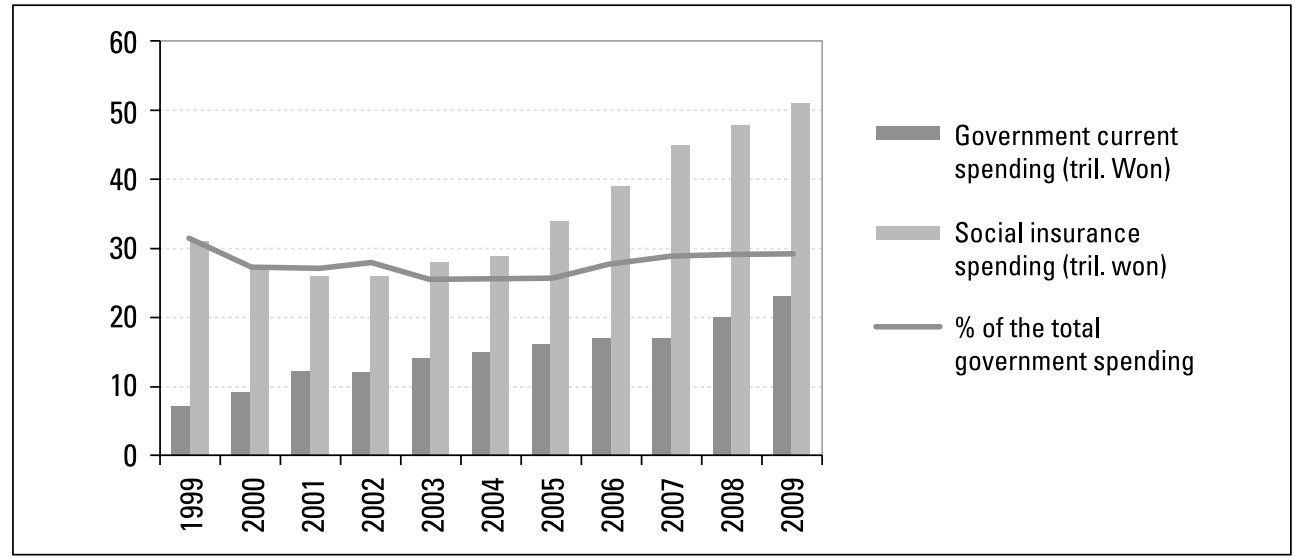

Source: National Statistical Office (http://kostat.go.kr)

Figure 4 captures the overall picture of Korean government spending on social protection. As the existing social programs have matured over the last ten years, overall spending in nominal terms has increased. In particular, expenditure on social insurance has steadily increased, mainly due to the National Pension Program and National Health Insurance, which have now matured. Allocations in the current government 
budget, though smaller than those for social insurance, have been on the rise. Nevertheless, this does not mean that the policy commitment has been stronger, since social spending's proportion of total government spending has remained at almost the same level as in the last ten years.

In a nutshell, the existing social policies of the welfare state, structured at the end of the 1990s, responded reasonably well to the global economic crisis. Does this mean that the welfare state in Korea will cope well with social risk in the future? Although it has been able to deal with challenges of social protection in the face of the global economic crisis, there is likely to be strong demand for a more extensive welfare state, not only for social protection but also for economic development. Dramatic demographic transition and family changes in Korea manifest this point clearly.

Demographic aging will be one of the most important issues facing the welfare state in Korea. It will inevitably increase the number of people who need social protection, notably income maintenance and health care for the elderly. For example, the number of pensioners will rise sharply, which will put huge pressure on the pension fund. Regarding health care, expenditures will soar at a high speed as an increasing number of elderly people will use health care services while demanding a much higher and more expensive quality of medical service than before. Other social services will also be increasingly necessary to meet the needs of the elderly.

It is true that demographic aging is happening in most OECD countries and a great number of developing countries as well. What is different in Korea and other East Asian countries is that the speed and scale of aging is faster and greater than other OECD countries. Table 5 shows that the speed of demographic aging in Korea is even faster than in Japan, where social policy has been restructured to meet the social needs of the elderly for the last two decades.

Table 5. Speed of Demographic Aging

\begin{tabular}{lcccccc}
\hline & \multicolumn{2}{c}{ Year reaching the proportion of the elderly } & & \multicolumn{2}{c}{ Time span of percentage increase } \\
\cline { 2 - 3 } \cline { 7 - 8 } & $7 \%$ & $14 \%$ & $20 \%$ & & $7 \%$ to $14 \%$ & $14 \%$ to $20 \%$ \\
\hline Korea & 2000 & 2019 & 2026 & & 19 & 7 \\
Japan & 1970 & 1994 & 2006 & & 24 & 12 \\
France & 1864 & 1979 & 2020 & & 115 & 41 \\
USA & 1942 & 2013 & 2028 & & 71 & 15 \\
\hline
\end{tabular}

Source: National Statistical Office (http://kostat.go.kr)

At the same time, however, it is worth noting that the other side of the story of demographic aging in Korea. The reason why Korea is witnessing the fast aging is that she has enjoyed a demographic gift for the last thirty years: an increasing working 
population with a better productivity rate than that of the previous generation. It has been a double boost for economic growth. It seems likely that Korea will enjoy this demographic gift until 2017. As figure 5 shows, however, pay-back time is coming with demographic loss due to the decreasing number of children

Figure 5. Demographic Structure in Korea

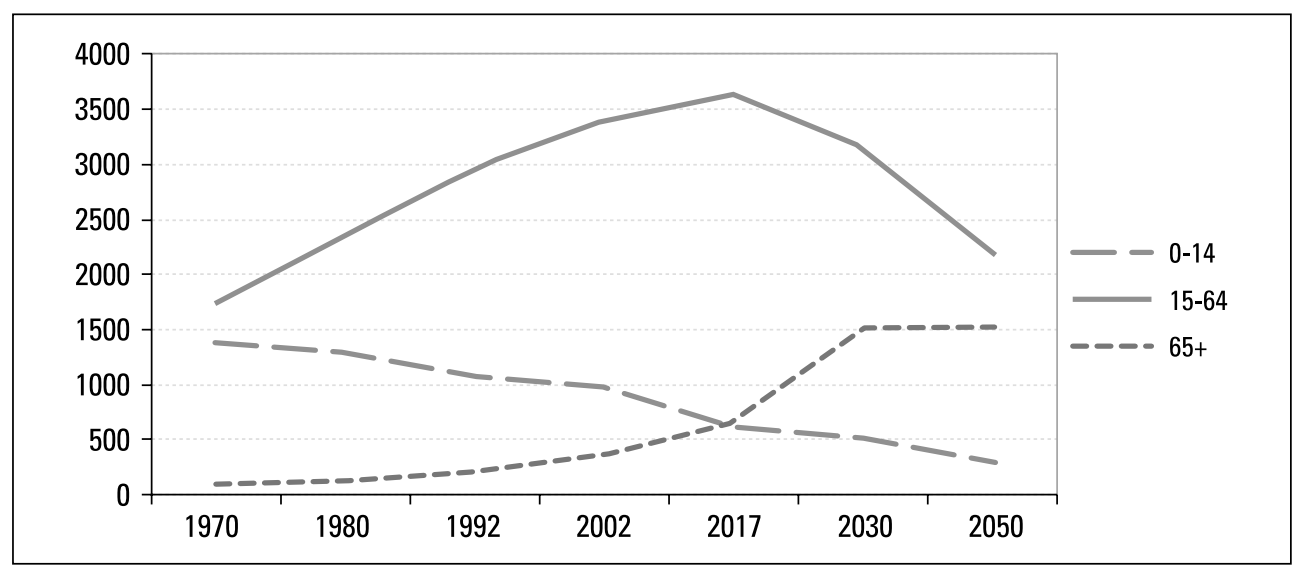

Source: National Statistical Office (http://kostat.go.kr)

Underlying this dramatic demographical transition is Korea's extremely low fertility rate- the lowest in the world at 1.17 (CIA 2009), even lower than that of Japan. It is a response, inter alia, to the Korean welfare state's inadequate social protection for children and women. One of the main reasons for the low fertility rate is private expenditure for children's education. Most parents think that education at school is not enough to get a place in a good university, and they spend a large portion of family income for private lessons for their children. Because of the high expenditure for education, families choose to have only one or two children. In addition, there has been inadequate social support for young nuclear families to raise their children. For such families, it is very difficult to balance work and family life. While there are not sufficient care facilities for children, it is fair to say that women are discriminated against in the workplace because of their responsibilities for caring for children at home. To sum up, Korea's low fertility rate is a response to the lack of family- and child-friendly social policies.

For this reason, women's participation in the labor market has stagnated over the last ten years despite their high educational attainment in Korea (see table 6). This is due not only to the inadequate support for women with children but also to women's precarious status in the labor market. Table 7 shows that more than 60 percent of employed women are in short-term or temporary employment. Underlying these data, 
there is a tendency for women to quit their jobs when they have children and return to work after a few years when children need less care. When they do, they are more likely to find temporary or short-term work (see table 7). Reflecting on these data, it is clear that women working in the labor market find their job status precarious, while other women tend to stay away from the labor market.

Table 6. Labor M arket Participation Rate by Gender in Korea (\%)

\begin{tabular}{|c|c|c|c|c|c|c|c|c|c|c|}
\hline & 1970 & 1975 & 1980 & 1985 & 1990 & 1995 & 2000 & 2005 & 2007 & 2008 \\
\hline Men & 77.9 & 77.4 & 76.4 & 72.3 & 74.0 & 76.4 & 74.2 & 74.4 & 74 & 73.5 \\
\hline Women & 39.3 & 40.4 & 42.8 & 41.9 & 47.0 & 48.4 & 48.6 & 50.0 & 50.2 & 50.0 \\
\hline
\end{tabular}

Source: National Statistical Office (http://kostat.go.kr)

Table 7. Employment Status by Gender in Korea (\%)

\begin{tabular}{llllllll}
\hline \multirow{2}{*}{ Men } & & 1990 & 1995 & 1997 & 1998 & 2000 & 2005 \\
& Regular & 64.5 & 67.6 & 64.6 & 64.7 & 59.2 & 62.3 \\
\multirow{3}{*}{ Women } & Temporary & 25.5 & 32.4 & 35.4 & 41.9 & 40.8 & 37.7 \\
& Regular & 37.6 & 42.8 & 38.4 & 34.8 & 31.1 & 38.2 \\
& Temporary & 62.4 & 57.2 & 61.6 & 64.2 & 66.9 & 61.8 \\
\hline
\end{tabular}

Source: National Statistical Office (http://kostat.go.kr)

In a nutshell, the demographic transition and emerging pattern of family and work life indicate that the welfare state in Korea should be strengthened to provide adequate support for the family. Otherwise, the long-term growth potential of the economy will be seriously undermined. For together with a quickly aging population, and a decreasing influx of young people to the labor market, women's stagnating participation seriously undermines the economic potential of the Korean economy.

\section{CONCLUDING REMARKS}

The welfare state in Korea has evolved over the last four decades from a bare structure of programs for industrial workers to a comprehensive system. The transformation of the welfare state in Korea took place in the wake of the East Asian economic crisis of 1997-98. The Employment Insurance Program, which was extended during the economic crisis, and the Minimum Living Standard Guarantee are a case in point. Although the welfare state was extended in terms of coverage and strengthened in terms of benefits by the reform, it was essentially aimed to facilitate labor market 
reform and the transition of Korea from a labor-intensive to a high-skilled economy.

Faced with a global economic downturn triggered by the U.S. subprime mortgage crisis, the instruments for social protection within the Korean welfare state, particularly the Minimum Living Standard Guarantee and the Employment Insurance Program, responded well to rising social risks. The Korean government also implemented extra policy measures to weather the difficult conditions in the labor market. The main focus of those policy responses was to provide income supports for poor and nearpoor families and to encourage firms to retain their workers. These policies were implemented through the existing policy framework. Overall, the welfare state in Korea seemed to function effectively during the global economic crisis. The secular trend in social spending also seems to suggest that social protection has been further strengthened.

Yet the question remains whether Korea will be able to take on future challenges for social protection and economic development with the existing policy arrangement. The future demographic transition and change in family structure will be most difficult challenges for social protection and economic development. While the rapid aging of the population will put a great deal of pressure on the welfare state, inadequate policy support for working women and families with children, together with the economic burden of paying for children's education, has resulted in an extremely low fertility rate. Without adequate policy responses, the economic and social potential for economic development will easily evaporate in the near future. This could be another defining moment for the welfare state in Korea.

There should be three strands of policy responses to these challenges. First and most immediately, the number of the care facilities for children and the elderly should increase, and their economic and geographic accessibility should be enhanced. The Long-Term Care Insurance introduced in 2008 would be a good basis for further development, but there should be more efforts to increase the number of public childcare facilities. So far, the government has tried to increase the number of child-care facilities using a market-oriented approach. This did work to some extent, but with limitations.

Second, it is necessary to address gender inequality in the labor market. Such inequality has prevented women from participating in the labor market and has allowed them only to have temporary jobs when they return to the labor market after caring for young children. As briefly discussed in the paper, the current trend shows no significant improvement in this area.

Third, in the long term, it is necessary for Korean society to reconsider the balance between work and life. While women are overextended between their work and childcare commitments, Korean men also seem to work extremely long hours, the highest 
among the OECD countries. So much concentration on work will have self-defeating effects, undermining productivity and reproduction, which will ultimately undercut Korea's potential for economic growth.

\section{REFERENCES}

Asian Development Bank. 2002. Asian Development Outlook. http://www.adb.org/ Documents/Books/ADO/. . 2005. Asian Development Outlook. http://www.adb.org/Documents/Books/ $\mathrm{ADO} /$.

CIA (Central Intelligence Agency). 2009. The World Factbook. http://www.cia.gov/ library/publications/the-world-factbook/.

Employment Insurance Corporation. 2001. Employment Insurance Review (in Korean). Seoul: Employment Insurance Corporation.

Goodman, R., and G. White. 1998. Welfare Orientalism and the Search for an East Asian Welfare Model. In R. Goodman, G. White, and H. J. Kwon (ed.), The East Asian Welfare Model: Welfare Orientalism and the State. London: Routledge.

He, X., and Y. Cao. 2007. Understanding High Saving Rate in China. China \& World Economy, 15:1-13.

Holliday, I. 2000. Productivist welfare capitalism: Social policy in East Asia. Political Studies, 48:706-23.

Im, B. I. 2009. The Role of Social Policy for Poverty Reduction in the context of Global Economic Crisis. International Trade Business Institute Review, 15(1): 59-91

Korea Employment Information Service. 2010. Employment Issues, 3(2):1-126. http://www.keis.or.kr/

Kwon, H. J. 1999. The Welfare State in Korea: The Politics of Legitimation. London: Macmillan.

2001. Income transfers to the elderly in Korea and Taiwan. Journal of Social Policy, 30: 81-93.

. 2005. Transforming the developmental welfare state in East Asia. Development and Change, 36: 477-97.

Kwon, H. J., and Yi, I. C. 2009. Economic Development and Poverty Reduction in Korea: Governing Multifunctional Institutions. Development and Change, 40: 769-92.

National Statistical Office. //Kostat.go.kr.

Park, B. G. 2001. Labor regulation and economic change: A view on the Korean eco- 
192 Economic Crises and the Welfare State in Korea

nomic crisis. Geoforum, 32:61-75.

Wade, R. 1990. Governing the market: Economic theory and the role of government in East Asian industrialization. Princeton, NJ: Princeton University Press.

World Bank. 2006. World Development Report 2006. Washington DC: World Bank.

Yi, I. C. 2007. The Politics of Occupational Welfare in Korea. Fukuoka: Hana-Syoin. 